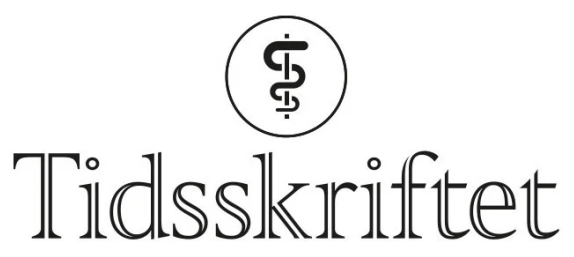

DEN NORSKE LEGEFORENING

\title{
Flekker i benmargen
}

MEDISINEN I BILDER

ANN ELISABETH ELLINGSEN

ann.ellingsen@unilabs.com

Unilabs Røntgen, Haugesund

Ann Elisabeth Ellingsen er spesialist i radiologi.

Forfatteren har fylt ut ICMJE-skjemaet og oppgir ingen interessekonflikter.

\section{CAMILLA STAPNES BJØRNSEN}

Medisinsk avdeling

Helse Fonna, Haugesund sjukehus

Camilla Stapnes Bjørnsen er ph.d., spesialist i hematologi og overlege.

Forfatteren har fylt ut ICMJE-skjemaet og oppgir ingen interessekonflikter. 


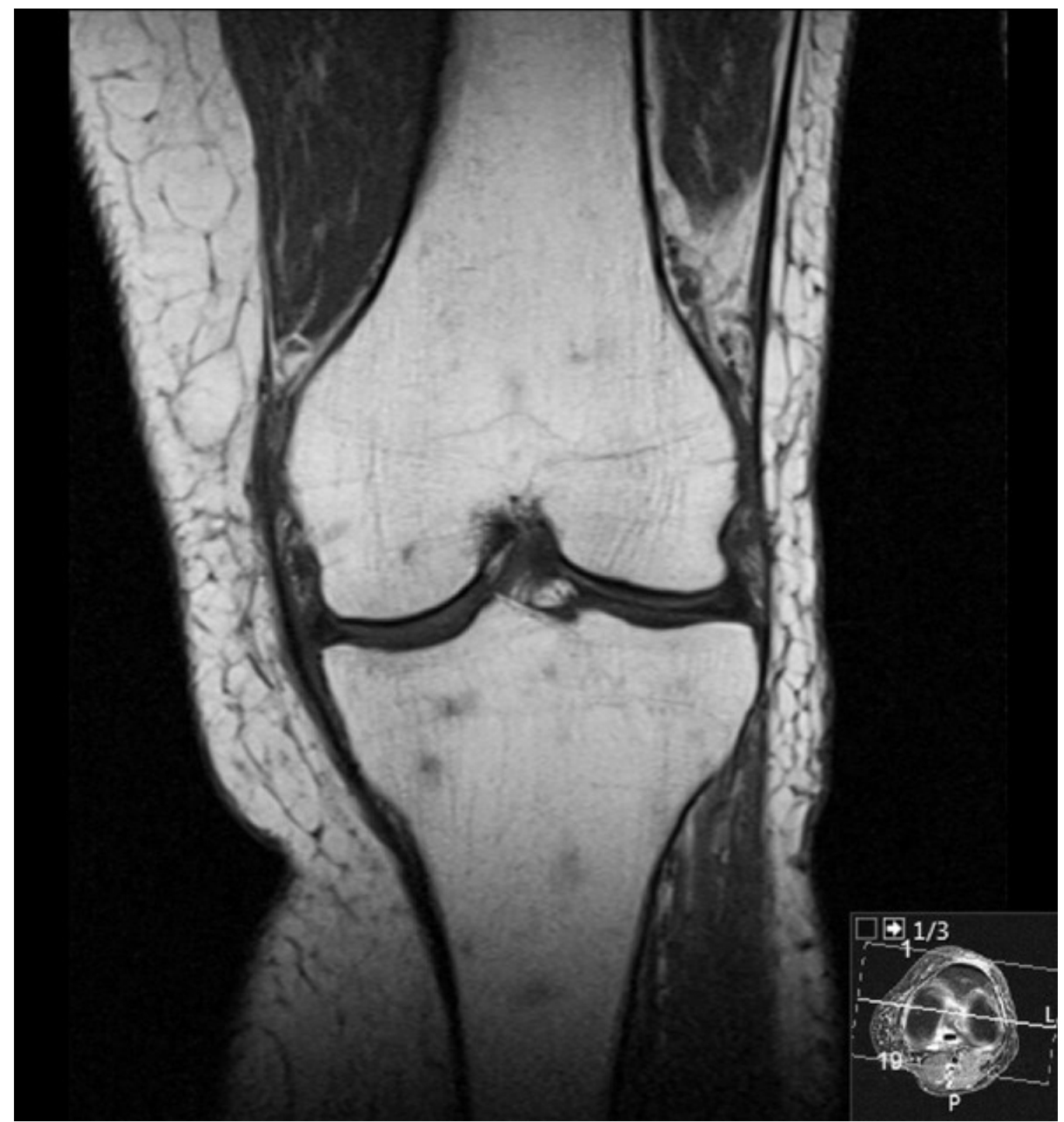

MR-bildet av venstre kne viser flekkvise forandringer med lavt T1-signal i benmargen.

En tidligere frisk kvinne i 7o-årene kom til MR-undersøkelse av venstre kne på grunn av et halvt år med smerter i kneet, spesielt ved kneling og trappegang. MR-undersøkelsen viste en degenerativ meniskruptur, som sannsynligvis kunne forklare pasientens symptomer. I tillegg var det flekkvise forandringer i benmargen.

Små signalvariasjoner i benmargen er ikke et uvanlig funn, men i dette tilfellet var funnet mer uttalt enn normalt. Funnet var også til stede på øvrige MR-sekvenser og ga mistanke om at det kunne foreligge sykdom med affeksjon av benmargen. Pasienten ble henvist til fastlegen for videre utredning. CT-undersøkelse av brystkassen, buken og bekkenet med intravenøst kontrastmiddel viste forstørrede lymfeknuter i mesenteriet og leverhilum samt lett forstørret milt.

Pasienten ble henvist til hematolog. Benmargsbiopsi viste $30 \%$ monoklonale plasmaceller (lambda-lettkjeder). I serum ble det påvist 32,8 mg/l (referanseområde 6,70-22,4 mg/l) frie kappa-lettkjeder og $1170 \mathrm{mg} / \mathrm{l}$ (8,30-27,o mg/l) frie lambda-lettkjeder, som er forenlig med myelomatose.

Pasienten fikk behandling med lenalidomid og deksametason med god partiell respons. Behandlingen måtte imidlertid avsluttes, da hun i forløpet fikk påvist annen sykdom, som hun døde av halvannet år etter at MR-bildet ble tatt.

Bifunn på radiologiske undersøkelser er ikke uvanlig, men de fleste er uten klinisk betydning. I noen tilfeller, som dette, er bifunnet alvorligere enn tilstanden som førte til undersøkelsen. Det er også tidligere rapportert om tilfeldig funn av hematologisk sykdom ved billeddiagnostikk (1). 
Pasientens pårørende har gitt samtykke til at artikkelen blir publisert.

Artikkelen er fagfellevurdert.

\section{LITTERATUR}

1. Grønningsæter IS, Ahmed AB, Vetti N et al. Bone marrow abnormalities detected by magnetic resonance imaging as initial sign of hematologic malignancies. Clin Pract 2018; 8: 1061. [PubMed] [CrossRef]

Publisert: 28. september 2020. Tidsskr Nor Legeforen. DOI: 10.4045/tidsskr.20.0021

Mottatt 7.1.2020, første revisjon innsendt 20.3.2020, godkjent 26.5.2020.

(C) Tidsskrift for Den norske legeforening 2023. Lastet ned fra tidsskriftet.no 26. april 2023. 